\title{
Public debt sustainability in sub-national level: a case of Karnataka
}

\section{R. Anantha Ramu ${ }^{1}$ iD}

Accepted: 16 May 2021 / Published online: 28 May 2021

(c) Editorial Office, Indian Economic Review 2021

\begin{abstract}
This paper attempts to empirically measure the public debt sustainability of Karnataka State in India for the period starting from 1991 to 2018. Three well-established methods are adopted to measure public debt sustainability, namely, indicator approach, time series approach and sensitivity analysis. The indicator approach shows that Karnataka's public debt satisfies Domer (1944) debt sustainability condition. Both the unit root test and fiscal policy response function under the time series approach revealed that public debt is sustainable and the response function is positive and significant in the post-fiscal reform period. Forward-looking sensitivity analysis has indicated public debt sustainability even after including growth rate and interest rate risks. Fiscal distress caused by the COVID-19 pandemic and corrective measures taken by Karnataka state is also discussed in the paper.
\end{abstract}

Keywords Fiscal policy $\cdot$ Debt sustainability $\cdot$ Time series approach $\cdot$ Sensitivity analysis $\cdot$ Fiscal policy response function

JEL Classification C22 - E62 - H63 · H68

\section{Introduction}

Among the Indian states, Karnataka is a frontrunner in fiscal management by adhering to its laid down fiscal management principles since the enactment of the Karnataka Fiscal Responsibility Act (KFRA) in 2002. Many factors determine the committed fiscal roadmap of the government. Despite being a frontrunner state in fiscal management, factors like political economy factors, the decline in economic growth rate, natural calamities, reduction in revenue buoyancy, increase in committed expenditure, and declining share in 15th Finance Commission's transfers, etc. have contributed to the upward trend in fiscal deficits and liabilities of Karnataka

M. R. Anantha Ramu

anantharamu.m.r@gmail.com

1 Fiscal Policy Institute, Government of Karnataka, Kengeri, Bengaluru, Karnataka 560060, India 
in recent years. In addition, budgetary obligations to increase transfers to local bodies as per the Third State Finance Commission (SFC) recommendations, mandatory earmarking of funds for Special Component Sub-Plan and Tribal Sub-Plan, minimum maintenance expenditure to be provided to road, bridges and irrigation projects as prescribed by the Thirteenth Finance Commission, special earmarking of funds within the budget to Hyderabad-Karnataka region (now renamed as Kalyana Karnataka region) development are the key fiscal challenges to prudent management of liabilities (GoK, 2014). In the context of growing expenditure commitments of the State, this paper attempts to empirically examine whether the Karnataka's debt is sustainable? Besides the analysis of debt sustainability, the paper tries to assess major risks that could derail Karnataka's sustainable path.

Debt sustainability analysis at the sub-national level is one of the highly debated issues in public finance literature. In the Indian context, there are many comparative studies on the states using panel data approaches. However, a detailed empirical analysis of debt sustainability on individual state using time series methodology and sensitivity analysis is limited. The fact is true with regard to Karnataka, where there are no such studies. In this background and in the background of concerns raised above, this paper attempts to answer whether Karnataka's public debt is sustainable using three well-established empirical methods, namely indicator approach, time series approach and forward-looking sensitivity analysis accommodating growth and interest rate risk factors.

The remainder of the paper is organized as follows. Section two presents the analysis of trends and composition of public debt in Karnataka from 1990-91 to 2017-18. A brief review of relevant and important literature is presented in the third section. A detailed description of the methodological approaches adopted in the paper is given in the fourth section. Empirical results are presented and discussed in the fifth section and the final section concludes the paper.

\section{Trends and composition of public debt in Karnataka}

Trends in the total liabilities of Karnataka are presented in Fig. 1. Total liabilities, which was around 13\% of Gross State Domestic Product (GSDP) in 1998-99, went up drastically to $21.5 \%$ in $2003-04$. Factors that have contributed to a rise in deficits and debt were deceleration of own revenue as well as central transfers to the state government, revision of salaries and pensions (Rao \& Choudhury, 2004). The expenditure on debt servicing, implicit and explicit subsidies, losses in the power sector have contributed to the worsening fiscal situation.

To take corrective measures and to bring back the fiscal health, the State Government placed a 'White Paper on Karnataka State Finances' in the Legislature during March 2000. The White Paper identified the reasons for the deteriorating fiscal position and also highlighted the directions and guidelines for undertaking corrective measures (GoK, 2001). The vicious circle of increasing interest payments feeding into deficits and debt stock, decrease in revenues, increase in implicit subsidies, the dismal financial performance of public utilities and enterprises, fast expansion of public expenditure within the revenue account, declining productivity of public 


\section{Outstanding Liabilities (as \% of GSDP)}

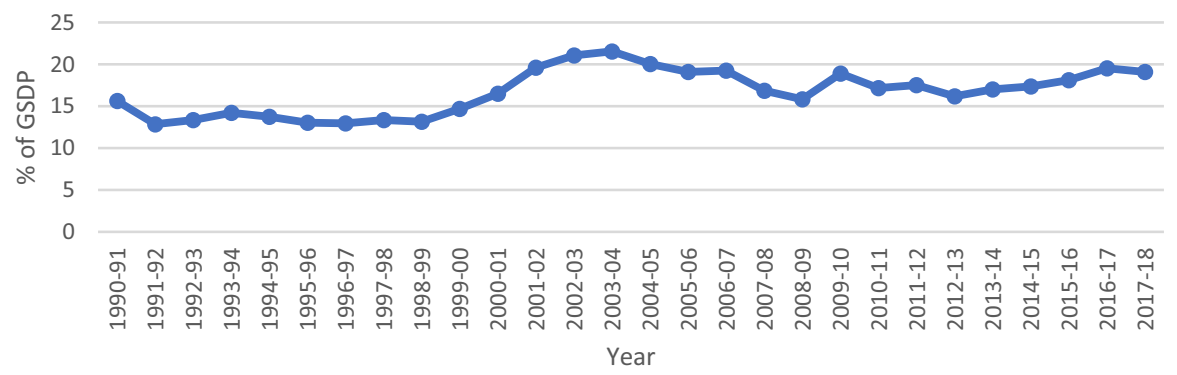

Fig. 1 Outstanding Liabilities (as \% of GSDP). Source: RBI, 2020

expenditure, etc., were highlighted as major causes behind worsening fiscal situation (GoK, 2001). Given the magnitude of the problem, it was emphasized in the White Paper that fiscal correction cannot be achieved in 1 or 2 years and it emphasized having an explicit medium-term fiscal framework for the State Government. In the Karnataka State Budget 2002-03, the Finance Minister of the State proposed to make the Medium-Term Fiscal Plan document a rolling annual document which would provide an outlook of the fiscal situation in the medium term and to provide legislative backing to the objective of achieving fiscal balance, the Fiscal Responsibility Bill was introduced in the same budget. Subsequently, the Karnataka Fiscal Responsibility Act was enacted in August 2002. With this, Karnataka was the first state to introduce a rule-based fiscal consolidation path in India even before the Central Government. With the introduction of the Karnataka Fiscal Responsibility Act, 2002, there was a declining trend in deficits and liabilities.

Meanwhile, guarantees on the loans taken by Parastatals of the State Government were another area of concern. Parastatals of the Government do borrow from the open market with a guarantee from the State Government. The Government guarantees went up substantially during the late 1990s. Meanwhile, to control the same, the Government has introduced a cap on guarantees by enacting the 'Ceiling on the Government Guarantees Act' in 1999.

Fiscal reforms in Karnataka was supplemented by many of the schemes introduced by Government of India to incentivize the State Governments to adopt fiscal consolidation path like Debt Swap Scheme, Debt Relief and Reform Facility as recommended by 11 th and 12th Finance Commission. For instance, the Debt Swap Scheme of the Government of India benefitted the State Governments in reducing their interest burden. As per the scheme, State Governments were allowed to borrow from the open market and repay the Government of India's high-cost loans. Average debt servicing cost reduced from more than $13 \%$ to less than $8 \%$ on account of the Debt Swap Scheme and lower cost open market borrowings.

As recommended by the Twelfth Finance Commission a general debt relief with rescheduling and lower interest rate may be available to States with effect from the year, they enact Fiscal Responsibility legislation. The Twelfth Finance 
Table 1 Components of outstanding liabilities (in INR Billion)

\begin{tabular}{|c|c|c|c|c|c|c|}
\hline Year & Market loans & NSSF & $\begin{array}{l}\text { Loans from } \\
\text { banks and } \\
\text { FIs }\end{array}$ & $\begin{array}{l}\text { Loans and } \\
\text { advances from } \\
\text { centre }\end{array}$ & Other liabilities & $\begin{array}{l}\text { Total outstanding } \\
\text { liabilities ( } \% \text { to } \\
\text { GSDP) }\end{array}$ \\
\hline 1 & 2 & 3 & 4 & 5 & 6 & 7 \\
\hline 1990-91 & $\begin{array}{l}8.7 \\
(14.7)\end{array}$ & $\begin{array}{l}0 \\
(0.00)\end{array}$ & $\begin{array}{l}1.08 \\
(1.8)\end{array}$ & $\begin{array}{l}30.1 \\
(51.0)\end{array}$ & $\begin{array}{l}19.11 \\
(32.4)\end{array}$ & $\begin{array}{l}58.99 \\
(15.61)\end{array}$ \\
\hline $2000-01$ & $\begin{array}{l}44.91 \\
(17.7)\end{array}$ & $\begin{array}{l}19.94 \\
(7.9)\end{array}$ & $\begin{array}{l}11.96 \\
(4.7)\end{array}$ & $\begin{array}{l}102.56 \\
(40.5)\end{array}$ & $\begin{array}{l}73.65 \\
(29.1)\end{array}$ & $\begin{array}{l}253.02 \\
(16.49)\end{array}$ \\
\hline 2010-11 & $\begin{array}{l}245.6 \\
(26.3)\end{array}$ & $\begin{array}{l}214.4 \\
(22.9)\end{array}$ & $\begin{array}{l}27.6 \\
(3.0)\end{array}$ & $\begin{array}{l}105.2 \\
(11.3)\end{array}$ & $\begin{array}{l}341.7 \\
(36.6)\end{array}$ & $\begin{array}{l}934.5 \\
(17.15)\end{array}$ \\
\hline 2011-12 & $\begin{array}{l}317.7 \\
(29.9)\end{array}$ & $\begin{array}{l}205.9 \\
(19.4)\end{array}$ & $\begin{array}{l}29.7 \\
(2.8)\end{array}$ & $\begin{array}{l}110.1 \\
(10.4)\end{array}$ & $\begin{array}{l}397.5 \\
(37.5)\end{array}$ & $\begin{array}{l}1060.9 \\
(17.50)\end{array}$ \\
\hline $2012-13$ & $\begin{array}{l}321.6 \\
(28.5)\end{array}$ & $\begin{array}{l}200.7 \\
(17.8)\end{array}$ & $\begin{array}{l}34.2 \\
(3.0)\end{array}$ & $\begin{array}{l}116.6 \\
(10.3)\end{array}$ & $\begin{array}{l}453.5 \\
(40.3)\end{array}$ & $\begin{array}{l}1126.6 \\
(16.20)\end{array}$ \\
\hline 2013-14 & $\begin{array}{l}533.3 \\
(38.4)\end{array}$ & $\begin{array}{l}197.3 \\
(14.2)\end{array}$ & $\begin{array}{l}33.7 \\
(2.4)\end{array}$ & $\begin{array}{l}121.1 \\
(8.7)\end{array}$ & $\begin{array}{l}504.4 \\
(36.3)\end{array}$ & $\begin{array}{l}1389.8 \\
(17.01)\end{array}$ \\
\hline $2014-15$ & $\begin{array}{l}694.2 \\
(43.8)\end{array}$ & $\begin{array}{l}201.7 \\
(12.7)\end{array}$ & $\begin{array}{l}33.2 \\
(2.1)\end{array}$ & $\begin{array}{l}127 \\
(8.0)\end{array}$ & $\begin{array}{l}527.7 \\
(33.3)\end{array}$ & $\begin{array}{l}1583.8 \\
(17.35)\end{array}$ \\
\hline 2015-16 & $\begin{array}{l}843.3 \\
(45.4)\end{array}$ & $\begin{array}{l}217.3 \\
(11.7)\end{array}$ & $\begin{array}{l}34.82 \\
(1.9)\end{array}$ & $\begin{array}{l}130.21 \\
(7.0)\end{array}$ & $\begin{array}{l}631.32 \\
(34.0)\end{array}$ & $\begin{array}{l}1856.95 \\
(18.10)\end{array}$ \\
\hline $2016-17$ & $\begin{array}{l}1083.59 \\
(51.3)\end{array}$ & $\begin{array}{l}201.57 \\
(9.5)\end{array}$ & $\begin{array}{l}39.73 \\
(1.9)\end{array}$ & $\begin{array}{l}138.12 \\
(6.5)\end{array}$ & $\begin{array}{l}648.68 \\
(30.7)\end{array}$ & $\begin{array}{l}2111.69 \\
(19.54)\end{array}$ \\
\hline 2017-18 & $\begin{array}{l}1257.07 \\
(51.1)\end{array}$ & $\begin{array}{l}185.84 \\
(7.6)\end{array}$ & $\begin{array}{l}42.89 \\
(1.7)\end{array}$ & $\begin{array}{l}145.73 \\
(5.9)\end{array}$ & $\begin{array}{l}827.97 \\
(33.7)\end{array}$ & $\begin{array}{l}2459.5 \\
(19.10)\end{array}$ \\
\hline
\end{tabular}

RBI database on Indian States and medium-term fiscal plan of Government of Karnataka, various issues From column 2-6, values in the parenthesis indicate the percentage to Total Outstanding Liabilities and for column 7, values in the parenthesis indicate percentage to GSDP

Commission has framed a scheme of debt waiver based on fiscal performance linked to the reduction of revenue deficit and control of fiscal deficit by the states. The quantum of debt write-off of the repayment was linked to the absolute amount by which the revenue deficit has reduced in each successive year during the award period. If the revenue deficit is brought down to zero, the entire repayment during the award period of the Twelfth Finance Commission will be written off. Karnataka has gained the benefit of Rs. 14.3 billion as debt relief and Rs. 13.1 billion as interest relief (RBI, 2013). With these measures, liabilities have declined from $21.5 \%$ of GSDP in $2003-04$ to $15.8 \%$ in $2008-09$.

The global economic meltdown and consequent deficit spending by the Government have resulted in a rise in the liabilities during 2009-10. Liabilities as a\% to GSDP is on an increasing trend since 2012-13. Global slowdown again during 2012-13 and the decline in tax efforts during the year 2014-15 and 2015-16 were some of the important reasons (GoK, 2014).

With the change in trend, there are considerable changes in the composition of liabilities in Karnataka as provided in Table 1. During the year 1991, loans and advances from the Central government constituted $51 \%$ of total liabilities and 
other liabilities constituted $32 \%$ of total liabilities. Other liabilities include provident funds, reserve funds, deposits and advances and contingency funds. The share of NSSF was around 23\% of total liabilities during 2011 and it declined considerably thereafter and constituted around $12 \%$ in 2017. This decline was owing to the adoption of recommendations given by the Committee for Comprehensive Review of NSSF constituted by the Government of India during 2010. Committee recommended a new formula for sharing small savings between the Centre and States. Keeping in mind the same prescribed limit of fiscal deficit (3\% of GDP/GSDP) for both Centre and State Governments, the committee recommended equal share in borrowings from the NSSF between sovereign and subsovereign (GoI, 2011). It was noted that the interest rate on borrowings from NSSF was higher than the market rates and equal sharing would ensure equal burden-sharing between the Centre and States. Earlier, the mandatory share component for States was $80 \%$ of NSSF loans. However, States could opt on either $50 \%$ or $100 \%$ at the beginning of the fiscal year based on their administrative convenience. Following the recommendations, in view of a higher rate of interest on NSSF loans, Karnataka State opted for a 50\% share. This move reduced the share of NSSF over the years since 2012 (GoK, 2012). In 2018, market loans constituted $51 \%$ of total liabilities. Meanwhile, the Government of Karnataka has benefitted from many measures introduced by the Central Government to restructure the state finances like Debt Swap Scheme (DSS) and Debt Consolidation and Relief Facility (DC and RF). As per the DSS, the State Governments were allowed to borrow from the open market and repay the Government of India's high-cost loans. Average debt servicing cost reduced from more than $13 \%$ to less than $8 \%$ on account of DSS and lower cost open market borrowings (RBI, 2013). As per DC and RF, the general debt relief with rescheduling and lower interest rate shall be available to States with effect from the year they enact FRBM legislation (RBI, 2003). Moving from high-cost loans from Central Government to comparatively cheaper loans from the open market, benefits availed from DSS and DC and RF measures have contributed to keeping the fiscal consolidation on track and prudent debt management. Even though total liabilities are within the mandated threshold, it is increasing in recent years and appears to be a challenge for the State Government to control them.

As depicted in Fig. 1 and Table 1, total liabilities as a\% to GSDP and in absolute terms are on an increasing trend in Karnataka since 2012-13. Decline in economic growth, decline in tax efforts, decline in the buoyancy of own tax revenues, increase in committed expenditure, etc., are the major reasons behind this trend ${ }^{1}$ (CAG, 2020; GoK, 2019). Despite being the front runner in fiscal management, an increasing trend in the liabilities of Karnataka State in recent years raises the question on its

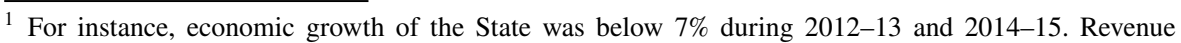
efforts (Revenue-GSDP ratio) of the State have declined from $1.37 \%$ in $2014-15$ to $0.71 \%$ in $2017-18$ and own tax revenue buoyancy declined from $1.03 \%$ in $2014-15$ to $0.34 \%$ in $2017-18$. Committed expenditure of the Government has remained above $80 \%$ of the revenue receipts of the state since $2013-$ 14. Interest payments as a percent of revenue receipts has increased from $9.4 \%$ in $2014-15$ to $10.18 \%$ in 2017-18.
} 
sustainability. In this background, this paper tries to assess whether the public debt of Karnataka is sustainable or not. In addition, this paper also tries to assess whether the rule-based fiscal consolidation contributed to the sustainability of the public debt of Karnataka. A brief review of relevant literature is presented in the next section.

\section{Literature review}

Fiscal sustainability implies the ratio of outstanding debt and debt servicing to GDP, in a steady state should not increase over time (IMF, 2011). There are many studies at the global level on the assessment of debt sustainability like Uctum et al. (2006), Afonso and Rault (2007) and Adams et al. (2010) to name a few. In the India context, Jha and Sharma (2001) measured the sustainability of India's public debt in the pre-independence (1871-1921) and post-independence (1950-1997) era. It was argued that if public expenditure and revenue are $\mathrm{I}(0)$, then the public debt is sustainable. But if they are I(1) and not cointegrated then it is unsustainable. By allowing endogenous structural breaks in unit root tests, revenue and expenditure series in the post-independence period were found to be trend stationary and, hence, sustainable. Contrary to this, Rajaraman and Mukhopadhyay (2004) found that India's public debt from 1952 to 1997 is unsustainable and needs fiscal correction to preserve solvency. A structural time series model was used to measure the sustainability of the undiscounted debt-GDP ratio. Even though the results in Jha and Sharma (2001) and Rajaraman and Mukhopadhyay (2004) are showing contrasting results with regard to debt sustainability of India, the results are not comparable owing to differences in the methodology and data sets used.

Buiter and Patel (1992) measured debt sustainability of Centre, States and Public Sector Undertakings in India from 1971 through 1989. Indian public debt was found to be unsustainable. Likewise, Goyal et al. (2004) assessed the debt sustainability of the Centre, States and General Government. The fiscal position of the Centre and States were individually found to be unsustainable and weakly sustainable for General Government. Pradhan (2014) analysed the sustainability of public debt of combined Centre and State governments covering the time period 1974 through 2011. Using unit root test and cointegration analysis public debt was found to be sustainable.

At the sub-national level in India, Misra and Khundrakpam (2009) analysed the debt sustainability of Indian states using the present value budget constraint approach. $^{2}$ Covering the study period from 1991-92 to 2007-08, the debt position of state governments was found to be unsustainable. A recent paper by Kaur et al (2017) measured the debt sustainability of 20 Indian states for the time period 1980-81 to 2015-16. The analysis was based on the empirical estimation of intertemporal budget constraint and fiscal policy response function in a panel data

\footnotetext{
${ }^{2}$ Sustainability of debt under this approach emphasizes solvency of the Government. This requires that the future primary surpluses should be sufficient to repay the current stock of public debt.
} 
framework. It was found that debt position at the State level is sustainable in the long run and cointegration holds between expenditure and revenue.

Ianchovichina et al. (2007) developed and presented a framework for sub-national fiscal sustainability analysis. The framework was applied to Tamil Nadu state in India. Using sensitivity analysis, it was found that risks to the fiscal outlook include interest rate shocks, fiscal pressure on the primary deficit through wage shocks, subsidy increase or decline in central revenue transfers. Although these shocks found are not threatening the debt sustainability of Tamil Nadu, their combined effect are having a serious consequence for debt sustainability. In another sub-national level debt sustainability analysis, Maurya (2013) analysed the debt sustainability of Uttar Pradesh in the pre-and-post-FRBM period covering 1991-2012. Using the indicator approach and present value budget constraint approach, it was found that debt is on the sustainable path in the post-reform period.

It may be summarised that, there are very few studies on the measurement of debt sustainability at the individual sub-national level in India in general and sophisticated analysis is hardly found on the State of Karnataka in particular. This paper would be a valuable addition in this context.

The literature on debt sustainability suggests different methods of analysing the sustainability of public debt. The most commonly used method is testing Domar's (1944) debt sustainability condition and subsequently measuring debt sustainability through sustainability indicators analysis. Advancement in debt sustainability literature suggests a time series approach and the forward-looking sensitivity analysis. This paper adopts all the three approaches to measure debt sustainability of Karnataka. A detailed description of methodological approaches adopted in the paper are explained in the next section.

\section{Methodology}

Given the research gaps and advanced methodological approaches identified in the literature on debt sustainability, this paper adopts the following three methods to assess the sustainability of public debt in Karnataka.

Debt sustainability indicator approach

ii. Time series approach and

iii. Sensitivity analysis

\subsection{Debt sustainability indicator approach}

Domer's (1944) debt sustainability method is the basic and traditionally used method for the measurement of debt sustainability. Domer sustainability condition states that real economic growth should be more than the real interest rate. Often, Domer debt sustainability condition is criticised as a narrow approach to assessing 
debt sustainability and several broad indicators were suggested in the literature (see Rajaraman \& Mukhopadhyay, 2004; Kaur et al. 2017) to measure the same. These indicators analyse the debt sustainability from different perspectives like changes in revenue account, the magnitude of debt servicing, etc.

\subsection{Time series approach}

The time series approach to the measurement of public debt sustainability has many advantages. One, assessment of time series properties of the individual variables have policy implications. Two, structural changes or breaks do exist in the variables and those changes can be taken care of in the time series analysis. Three, debt is the cumulative effect of past borrowings and hence, a backwards-looking indicator. The time series econometric technique is used on historically given time series data to draw policy inferences and also to forecast the future values given the past trend. In this paper, unit root test and fiscal policy response function are used to measure the debt sustainability under the time series approach. The methodological description of these tests is provided below.

\subsubsection{Unit root test}

The budget constraint of the government can be written as.

$$
\Delta B_{t}=-X_{t}+n_{t} B_{t-1},
$$

Where $B$ is a measure of Government debt (outstanding liabilities of the State), $X$ is primary surplus and $n$ is the ex-post interest rate on the outstanding stock of government liabilities. Adjusting Eq. 1 to inflation and dividing by GSDP, we arrive at the following:

$$
\Delta b_{t}=-x_{t}+r_{t} b_{t-1},
$$

where $b$ is the real debt-GSDP ratio, $x$ is primary surplus-GSDP ratio and $r$ is real interest rate.

Assuming perfect foresight, solving Eq. 2 forward and successively substituting out the future discounted measure, gives the $k$-period intertemporal budget equation.

$$
b_{t}=\delta_{t, k} b_{t+k}+\sum_{i=1}^{k} \delta_{t, i} x_{t+i}
$$

where $\delta_{t, k}=\prod_{x=1}^{k}\left(1+r_{t+x}\right)^{-1}$ is the time varying discount factor for $\mathrm{k}$ periods ahead.

As ' $k$ ' goes to infinity, $\lim _{k \rightarrow \infty} \delta_{t, k} b_{t+k}=0$. This is known as transversality condition and implies that debt market will not tolerate Ponzi game. If this condition holds then $b_{t}=\sum_{i=1}^{k} \delta_{t, i} x_{t+i}$ and intertemporal budget constraint is satisfied.

Fiscal policy is said to be sustainable if the initial stock of debt is equal to the sum of the present discounted value of the primary surplus. Alternatively, the present value of revenues must be equal to the present of spending including interest in 
the public debt plus repayment of debt itself (Kaur et al 2017). The intertemporal budget constraint is satisfied if the discounted sum of end period debt converges to zero. The intertemporal budget constraint thus imposes restrictions on the long-run relationship between expenditure and revenue of the government by requiring these two not to drift too far away from each other and the government to generate sufficient future net primary surpluses to pay back outstanding stock of debt (Uctum et al. 2006).

The usual method to investigate the transversality condition is to test the hypothesis, using historical data, that the Data Generating Process for discounted debt is non-stationary. Rejection of null of non-stationarity indicates that transversality condition holds. If the null hypothesis is not rejected then the present fiscal policy is not sustainable and needs a revisit.

In the time series analysis, the unit root test approach is generally used for testing sustainability. Under this approach, the stationarity test on the discounted value of the government debt is conducted on Eq. 2. The traditional approach to test stationarity is to use the Augmented Dickey-Fuller (Dickey \& Fuller, 1979) test as given below.

$$
\Delta b_{t}=\mu_{0}+\mu_{1} \text { Trend }+\Phi b_{t-1}+\sum_{i=1}^{n} \beta_{i} \Delta b_{t-i}+\varepsilon_{t}
$$

The null hypothesis of a unit root is $\Phi=0$ and $\mu_{1}=0$.

Generally, in the long run, structural changes in the economies are inevitable. The traditional unit root test approaches biases to result in non-rejection of the null hypothesis of a unit root when there is a structural break in the series. Perron (1989) points out that structural change and unit roots are closely related and conventional unit root tests are biased toward a false unit root null when the data are trend stationary with a structural break. Many of the studies like Jha and Sharma (2001) have proven this. To overcome this problem and to incorporate structural change in the regression, structural unit root test procedure laid down by Perron (1989), adapted by Zivot and Andrews (1992) and Vogelsang and Perron (1998) and as applied by Uctum et al. (2006) is used in this paper. Following this approach, the stationarity test for the variables, namely liabilities-GSDP ratio, expenditure-GSDP ratio and revenue receipts-GSDP ratio is conducted in this paper.

\subsubsection{Fiscal policy response function}

The response of primary surplus to variations in public debt is measured for the assessment of the health of fiscal policy and the sustainability of public debt. As per the Barro (1979) tax smoothing model, positive feedback from government debt to the primary surplus indicates stationarity in the debt variable. In case primary surplus is observed to be a positive function of public debt, it implies that rising debt ratios lead to higher primary surpluses, which is indicative of a tendency towards mean reversion and thus, debt sustainability (Kaur et al. 2017).

To measure the fiscal policy response function in Karnataka, a framework as developed by Uctum et al. (2006) and Kaur et al. (2017) is used in this paper. 


$$
x_{t}=\alpha+\beta_{1} b_{t-1}+\beta_{2} E_{t}+\beta_{3} y_{t}+v_{t} \text {, }
$$

where $x_{t}$ is the primary surplus as ratio to GSDP, $b_{t}$ is government liabilities as ratio to GSDP, $E_{t}$ is the government expenditure gap as ratio to GSDP, $y_{t}$ is output gap presented in the log terms. The expenditure gap is the difference between its trend and actual value. Trend values in expenditure are calculated using the HodrickPrescott filter method. Similarly, the output gap is also calculated. Expected signs in the equation are $\beta_{1}>0$, primary surplus is expected to decline with higher government spending $\left(\beta_{2}<0\right)$ and increase with deviation of output from its trend $\left(\beta_{3}>0\right)$. This test analyses whether the government tends to take offsetting adjustments when faced with rising debt by considering the relation between debt and primary balance (Uctum et al. 2006).

There are four possible results when both unit root test and fiscal policy response function is conducted simultaneously. These four possible results are summarised in Table 2.

\subsection{Sensitivity analysis}

\subsubsection{Analytical framework for sub-national debt sustainability analysis}

Fiscal sustainability analysis provides an indication whether or not a particular policy mix is sustainable. Burnside (2005) presents several ways of defining fiscal sustainability. One such definitions is linked to Solvency. It refers to a government's ability to service its debt obligations without explicitly defaulting on them. In similar lines, fiscal sustainability relates to a government's ability to indefinitely maintain the same set of policies while remaining solvent (Burnside, 2005). If particular combination of policies leads to insolvency, then it would be called as unsustainable.

The analytical framework is drawn from Ianchovinchina et al. (2007).

The intertemporal debt financing constraint of the sub-national government is

$$
B_{t}-B_{t-1}=n_{t} B_{t-1}-X_{t}
$$

where $B_{t}$ is outstanding liabilities of the State at the end of the period $t . X_{t}$ is primary fiscal balance in period $t$ and $n_{t}$ denotes domestic interest rate in period $t$. Equation 6 is the fundamental step for studying debt dynamics both in a historical and forwardlooking mode. For practical analysis, it is important to represent debt and government budget constraint in percentages of State income i.e., GSDP.

$$
b_{t}-\frac{b_{t-1}}{Z_{t}}=i_{t}-x_{t},
$$

where 


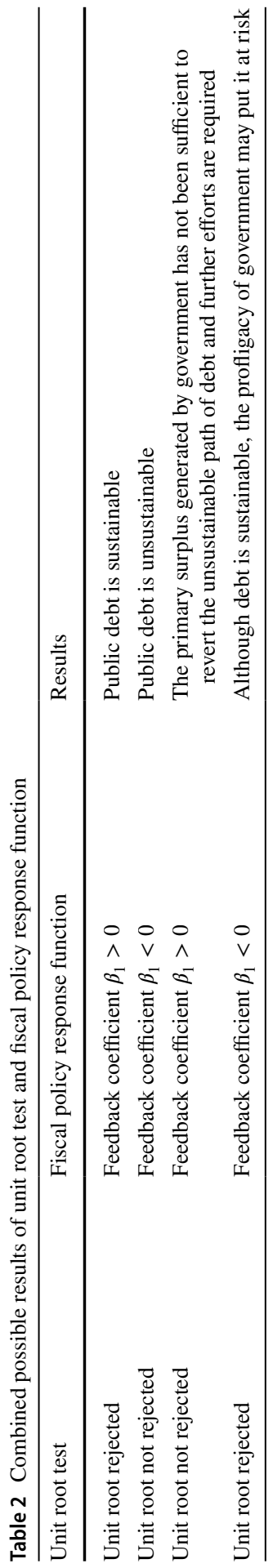




$$
b_{t}=\frac{B_{t}}{P_{t} Y_{t}}, Z_{t}=\frac{P_{t} Y_{t}}{P_{t-1} Y_{t-1}}, x_{t}=\frac{X_{t}}{P_{t} Y_{t}}, i_{t}=\frac{n_{t} B_{t-1}}{P_{t} Y_{t}} .
$$

$Y_{t}$ denotes output and $P_{t}$ is price level at period $t$.

To solve for change in debt, Eq. 7 can be modified using the following:

$$
\frac{Y_{t}}{Y_{t-1}}=1+g_{t}=G_{t}, \frac{P_{t}}{P_{t-1}}=1+\pi_{t}=\Pi_{t}, \text { and, } Z_{t}=G_{t} \Pi_{t}+\left(1+g_{t}\right)\left(1+\pi_{t}\right) \text {. }
$$

The growth and inflation effect on indebtedness can be obtained by solving the following equation:

$$
b_{t}-b_{t-1}=i_{t}-x_{t}-\frac{g_{t}}{Z_{t}} b_{t-1}-\frac{\pi_{t}}{\Pi_{t}} b_{t-1}
$$

where $g_{t}$ is the real annual growth rate, $\pi_{t}$ is the annual inflation rate, $i_{t}$ is the interest rate, $x_{t}$ is the primary balance, $\frac{g_{t}}{Z_{t}} b_{t-1}$ and $\frac{\pi_{t}}{\Pi_{t}} b_{t-1}$ are the growth effect and inflation effect on domestic debt, respectively.

With the given set of projections for interest rate, primary balance, growth and inflation rates, debt sustainability can be analyzed using following formula:

$$
b_{t}=\frac{\left(1+r_{t}\right)}{\left(1+g_{t}\right)} b_{t-1}-x_{t} \text {. }
$$

Equation 9 shows that sustainability of sub-national government's fiscal policies depends on the primary balance, the real interest rate and economic growth. Real interest rate depends on nominal interest rate and inflation. $r_{t}$ is calculated using $\frac{\left(n_{t}+1\right)}{\left(\pi_{t}+1\right)}-1$.

The results obtained using all the aforementioned approaches are discussed in the next section.

\section{Results and discussion}

\subsection{Results of indicator approach}

The results of the indicator approach are given in Table 3. Indicators are measured for the entire study period and also a comparison of pre- and post-Fiscal reforms (Karnataka Fiscal Responsibility Act, 2002) is presented. The first indicator measures Domer's debt sustainability condition. Debt level fulfils the Domer (1944) sustainability condition and it has improved further in the post-fiscal reform period. Similarly, the nominal growth of Karnataka's GSDP is more than the growth of public debt. As shown in the third indicator, Karnataka's primary balance is in deficit, however, the primary revenue balance is positive. ${ }^{3}$ The fifth indicator shows that the

\footnotetext{
${ }^{3}$ Primary balance denotes fiscal deficit minus interest payments and primary revenue balance denotes revenue deficit minus interest payments.
} 


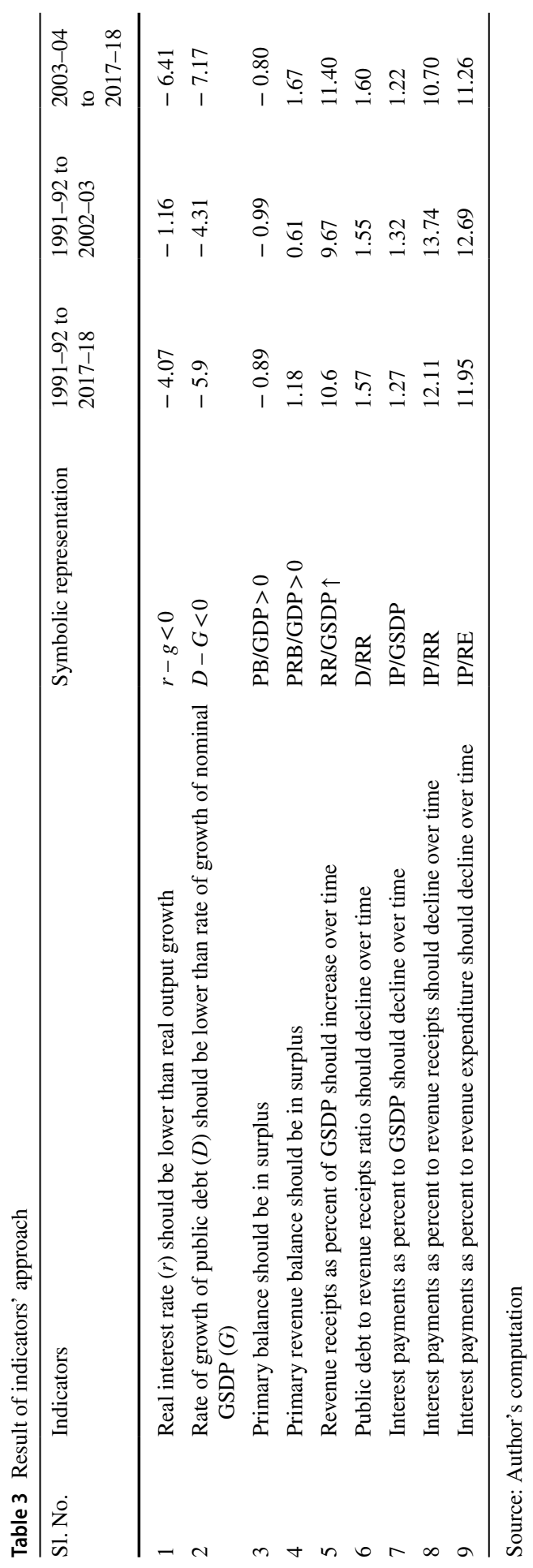


Table 4 Result of structural break unit root test

\begin{tabular}{llll}
\hline Variables (level) & Break date & ADF test statistic & $p$ value \\
\hline Liabilities-GSDP ratio & 2001 & $-4.06^{* * *}$ & 0.026 \\
Expenditure-GSDP ratio & 2003 & $-4.72^{* *}$ & 0.022 \\
Revenue receipts-GSDP ratio & 2003 & $-4.71^{* *}$ & 0.023 \\
\hline
\end{tabular}

Source: Author's calculation

**Indicates rejection of null hypothesis of non-stationarity at $5 \%$ level of significance

State's revenue receipts as a\% to GSDP is increasing over time. Karnataka is one of the best performing states in India with regard to revenue buoyancy and tax efforts (Gayithri, 2014; Gayithri et al. 2019). The cause of concern is that the public debt to revenue receipts has increased marginally in the post-reform period.

Debt servicing is another important component of debt sustainability analysis. As indicated in Table 3, interest payments as a\% to GSDP as well as to revenue receipts are declining in the post-reform period. In addition, its share in revenue expenditure is also declining to indicate a reduction in a portion of the committed expenditure of the Government. The indicator analysis clearly shows that the debt situation of Karnataka is prudent and sustainable.

\subsection{Results of time series analysis}

The result of the unit root test with a structural break is given in Table 4. Structural break date, Augmented Dickey-Fuller test statistic and its $p$ value (asymptotic onesided $p$ value as specified in Perron, 1989) is presented. Lag length is selected based on Schwarz information criteria.

Results of the structural break unit root test clearly indicate that all the three variables, namely liabilities, expenditure and revenue receipts, as a\% to GSDP are stationary at level i.e., I(0) with the inclusion of a structural break in the model. Stationarity of liabilities at level indicates the sustainability of public debt of Karnataka. As argued by Jha and Sharma (2001), if public expenditure and revenues are $\mathrm{I}(0)$ as in the present case, public debt is sustainable.

Results of the fiscal policy response function are presented in Table 5. The LM statistics shows that there is no serial correlation problem. Unit root test of the variables used in the regression and model stability tests, namely CUSUM and CUSUM of square test results, are given in Appendix 1. Model stability test proves that the model is stable. A dummy variable for the year 2003 is included in the model to assess fiscal response function in pre- and post-fiscal reforms in Karnataka. 
Table 5 Results of fiscal policy response function

\begin{tabular}{lll}
\hline Dependent variable: primary surplus-GSDP ratio \\
\hline Explanatory variables & $\begin{array}{l}\text { Estimated coefficient } \\
\text { value }\end{array}$ & $p$ value \\
\hline Constant & 1.01 & 0.55 \\
Liabilities-GSDP ratio (- 1) & -0.15 & 0.23 \\
Expenditure gap-GSDP ratio & -24.31 & 0.15 \\
Ln (Output gap) & 0.17 & 0.95 \\
Dummy 2003 & $-6.35^{*}$ & 0.00 \\
$\begin{array}{l}\text { Dummy 2003*Liabilities-GSDP } \\
\text { ratio (- 1) }\end{array}$ & $0.39^{*}$ & 0.00 \\
\hline
\end{tabular}

Source: Author's calculation

$R$ squared value: 0.39

Adjusted $R$ Squared value: 0.25

LM test Statistic ( $p$ value): $1.89(0.15)$

Expenditure gap and output gap though satisfy sign condition are found to be insignificant. This means that government expenditure has to be further contained and output needs a boost. The response of primary balance to liabilities found to be insignificant in the pre-reform period. However, it turns out to be significant in the post-reform period. $1 \%$ increase in liabilities-GSDP ratio leads to a positive change in primary balance by $0.24 \%$.

Rejection of unit root and negative feedback from liabilities to primary balance in the pre-reform period indicates that even though fiscal policy is sustainable, the profligacy of government may put it at risk. However, rejection of unit root, as well as positive fiscal response function in the post-reform period, clearly implies that Karnataka's public debt is sustainable.

\subsection{Results of sensitivity analysis}

Debt dynamics as measured in the sensitivity analysis should decline over time. Debt dynamics are estimated for the future given the historical averages or based on the assumptions. If debt dynamics are exponential, then the debt is not sustainable.

\subsubsection{Historical averages}

Debt dynamics based on the historical average (refer to Appendix 2) indicates the declining trend in debt of the Government. If the historical average prevails, then the debt is sustainable.

\subsubsection{Growth rate risks}

Several structural and cyclical factors are inevitable to an economy. These risks are incorporated while estimating the debt dynamics. One such risk may the growth rate 
risk. Debt is sustainable, as shown in Appendix 2, when the growth rate declines to $6 \%$ from the historical average of $6.92 \%$. Suppose the average real growth rate of the economy declines to $5.5 \%$ and further to $5 \%$, there will be challenges to debt sustainability. However, even with the decline in growth rate, debt dynamics are showing a declining trend keeping the level of real interest rate and primary balance constant. Debt is sustainable even with the growth rate risk. The situation may worsen if the economic growth rate declines further to $3 \%$ or below, then debt becomes unsustainable.

\subsubsection{Interest rate risks}

The demand and supply of loanable funds, international capital flows, etc. determines the rate of interest. State Government borrows within the domestic territory of India and, hence, most of the loans are internal. If there is a risk of an increase in real interest rate, then debt sustainability becomes challenging. However, as shown in Appendix 2, debt dynamics are declining when the rate of interest is assumed to be $4 \%, 4.5 \%$ and $5 \%$ keeping other variables constant. If the real interest rate goes further up to $6.5 \%$, then the debt becomes unsustainable.

\subsubsection{Growth rate and interest rate risks combined}

Most of the macroeconomic variables are interlinked. If there is a risk of both raising interest rate and declining growth rate, then prudent debt management becomes difficult. As shown in Appendix 2, if the real interest rate rises to 4\% and the real growth rate declines to $6 \%$ and further to $4.5 \%$ and $5.5 \%$, respectively, the debt dynamics shows a declining trend indicating the sustainability of public debt. However, a problem arises if the growth rate falls below $5 \%$ and the interest rate rises above $5 \%$.

Sensitivity analysis indicates that based on the historical average of primary balance, real growth rate and real interest rate public debt of the State is sustainable. The results hold even with the growth rate and interest rate risks. However, it becomes challenging for the government to keep debt on a sustainable path if there is a steep decline in the growth rate and a rise in the real interest rate.

\section{Discussion}

Many studies in the Indian context like Rangarajan and Srivastava (2005), Bal and Rath (2014) and Mohanty and Panda (2019) have observed that high and persistent public debt adversely affect the macro-economy in terms of creating inflationary pressure, raising the interest rate, reducing the economic growth and imbalances the external sector. Hence, public debt sustainability is a prerequisite for macroeconomic stability, intergenerational equity and economic growth. Decentralisation has given sub-national governments significant spending and taxation responsibilities 
and capacity to incur debt. Unsustainable fiscal policy at the sub-national level jeopardises service delivery, the safety of the country's financial system and macroeconomic stability (Ivanchovichina et al., 2007). A sustainable level of debt and prudent fiscal policy attracts more private investments with increased confidence in the investors. The fiscal discipline with having zero revenue deficits or a positive revenue balance will enable the State to spend more towards capital formation and supplement the private investments. The empirical results in this paper depict that Karnataka's debt is sustainable.

In addition to the reforms mentioned in Sect. 2, the Government of Karnataka has taken many initiatives to manage its liabilities within the laid down cap. Since 2005-06, all issuance of State Development Loans (SDLs) has a maturity of 10 years. However, since 2013-14, the State strategically went in for issuances of SDLs of varying tenures (GoK, 2014). The state undertook to flatten its redemption profile by spacing out the SDL maturity year by floating short-term bonds in addition to regular 10-year SDLs on the advice of the Reserve Bank of India. This helped the State in availing much cheaper funds. The state has not availed any special Ways and Means Advances from RBI since 2007-08. Cash surpluses with RBI above the prescribed limit is being invested in 14 days Treasury Bills and 91 days Treasury Bills as per the cash requirement without keeping it idle. The State is going for borrowings only in the third and fourth quarter where there will be a surge in expenditure and, hence, could save up on the interest burden in the first two quarters.

The emergence of the COVID-19 pandemic has paused the fiscal consolidation roadmap of the State. Even before the onset of the pandemic, the fiscal position of the State was under distress due to the reduced share of Karnataka in devolution as per the Fifteenth Finance Commission recommendations (GoK, 2020a, 2020b). When compared to Fourteenth Finance Commission recommendations, this decline amounts to nearly Rs. 11,215 crores. Added to it, the revenue position of the State was badly hit due to the COVID-19 pandemic. There was a drastic fall in Goods and Services Taxes, State excise duty realization, motor vehicle taxes, stamps and registration duties realization were nil in April 2020. There was an improvement in the revenue realization with the unlocking of the economy. The fiscal situation of Karnataka as of November 2020 in comparison with the previous year figures is provided in Appendix-3. When compared to previous year figures, there was a shortfall of own revenue realization of the State by $20 \%$ till November 2020 . With the shortfall, both the revenue expenditure and capital expenditure has to be reduced by $16 \%$ and $7 \%$, respectively. With the reduction in revenues and more than budgeted expenditure towards the health sector, the announcement of economic packages to the needy, advance releases of ration, etc., the fiscal deficit and public debt of the State have increased substantially. As of November 2020, the public debt of the State was Rs. 49,872 crores which account for $94 \%$ of Budget Estimates with a growth of $123 \%$ over the previous year. The Government was obligated to amend the Karnataka Fiscal Responsibility Act for 2020-21. The Government of Karnataka amended the Act in September 2020 by enhancing the fiscal deficit cap to 5\% of GSDP and mentioned that revenue deficits are inevitable this year. However, the debt-GSDP 
ratio remained unaltered as the debt level may reach around $22 \%$ to $23 \%$ of GSDP in 2020-21 which is within the threshold limit of $25 \%$ of GSDP. Even though the debt is within the prescribed limit, sustainability will be of concern unless the economy revives fully and revenue buoyancies reach the pre-COVID-19 level. The decline in Central transfers adds to the issue of debt sustainability. The government of Karnataka has taken many steps to control its expenditure. The Dearness Allowances has been frozen. All the recruitments, creation of new posts have been restricted for the year 2020-21. On the revenue front, excise duties have been raised and state duties on petrol and diesel were increased. Many other controlling measures are expected in 2021-22.

\section{Conclusion}

This paper attempted to measure the public debt sustainability of Karnataka State, which is one of the fiscally prudent states in India. Even though fiscal indicators are within the laid down limits of KFRA, an upward trend was observed in fiscal deficits and liabilities in recent years. Declining economic growth and consequent decline in revenue buoyancies, declining share in central transfers, mandatory budgetary earmarking as recommended by State Finance Commissions, increase in expenditure commitments of the state, etc. have prompted us to empirically examine the public debt sustainability in Karnataka.

The paper used historical as well as forward-looking approaches to measure the debt sustainability. Specifically, three methods were used for the measurement of debt dynamics in Karnataka, namely, indicator approach, time series approach and sensitivity analysis. Results of the indicator approach satisfied Domer (1944) debt sustainability condition. In the time series approach, two tests have been conducted. One is the unit root test with incorporation of possible structural breaks and the other is fiscal policy response function. Unit root test on liabilities, government expenditure and revenue series indicated that the series is $I(0)$ and hence sustainable. In the fiscal policy response function, it was observed that the response of primary balance to liabilities in the pre-reform period was insignificant. However, the fiscal response function was positive and significant in the post-reform period. Rejection of unit root and negative feedback from liabilities to primary balance in the pre-reform period indicates that even though fiscal policy is sustainable, the profligacy of government may put it at risk. However, rejection of unit root, as well as positive fiscal response function in the post-reform period, implies that Karnataka's public debt is sustainable. As a forward-looking approach, a sensitivity analysis was carried out on historical averages of the variables as well as incorporating different risks mainly the growth rate and interest rate risks which are inevitable to an economy. Even after the inclusion of such risks, the debt level of Karnataka was found to be sustainable. However, there is a challenge to debt sustainability if 
real economic growth rate declines below 5\% and real interest rate rises above 5\% simultaneously.

Introduction and proper implementation of the Karnataka Fiscal Responsibility Act, 2002 is one of the major contributory factors for achieving debt sustainability in Karnataka. Continuous adherence to laid down fiscal consolidation roadmap would keep the debt position of Karnataka State on the sustainable path. However, as observed in the empirical results, controlling excess expenditure and narrowing down the output gap would further help the government in achieving prudent primary balance. The committed expenditure as a\% to revenue receipts constitute $85 \%$ and leaves very less space for the Government to spend towards the capital formation. Medium term corrections on the expenditure side are required to moderate such expenditure (GoK, 2014). Similar to the economic growth trend at the national level, Karnataka's output growth has also slowed down. Reducing the output gap by providing policy stimulus to reach the potential output level in near future is needed to keep the debt on a sustainable path. A continuous downturn of the Indian economy in 2019 and the outbreak of the COVID-19 pandemic in 2020 would alter the estimated path of debt sustainability in Karnataka. However, the Government of Karnataka, known for its fiscal discipline may take necessary policy actions to bring back the fiscal indicators on track albeit with a pause in 2020 and 2021.

\section{Appendix 1}

Unit Root Test results of the variables used in Fiscal Policy Response Function and Model Stability Test (Table 6, Fig. 2).

CUSUM and CUSUM of squares tests indicate that the model is stable

Table 6 Unit root test results

\begin{tabular}{llll}
\hline Variables (level) & Break date & ADF test statistic & $p$ value \\
\hline Primary surplus-GSDP ratio & 2011 & $-3.65^{* *}$ & 0.04 \\
Expenditure gap-GSDP ratio & 2003 & $-4.37^{*}$ & 0.01 \\
Ln (output gap) & 2003 & -4.62 & 0.01 \\
\hline
\end{tabular}

$*$ and $* *$ indicates rejection of null hypothesis of non-stationarity at $1 \%$ and $5 \%$ level of significance, respectively. By applying traditional ADF unit root test, it was observed that primary surplus was $\mathrm{I}(0)$ at $10 \%$ level of significance, expenditure gap and output gap at $1 \%$ level of significance. 


\section{Stability Test Results}
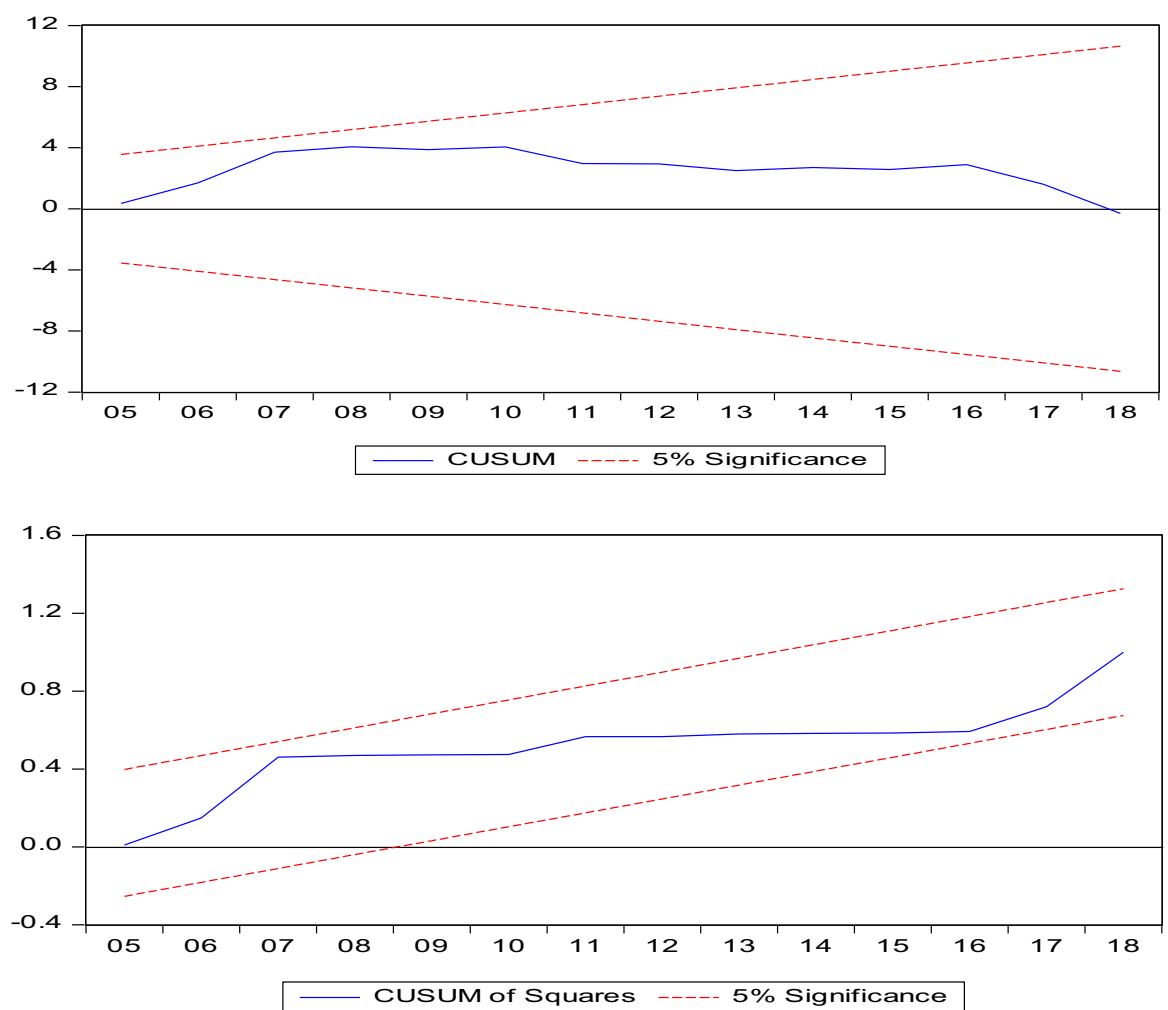

Fig. 2 Stability test results

\section{Appendix 2}

See Table 7. 


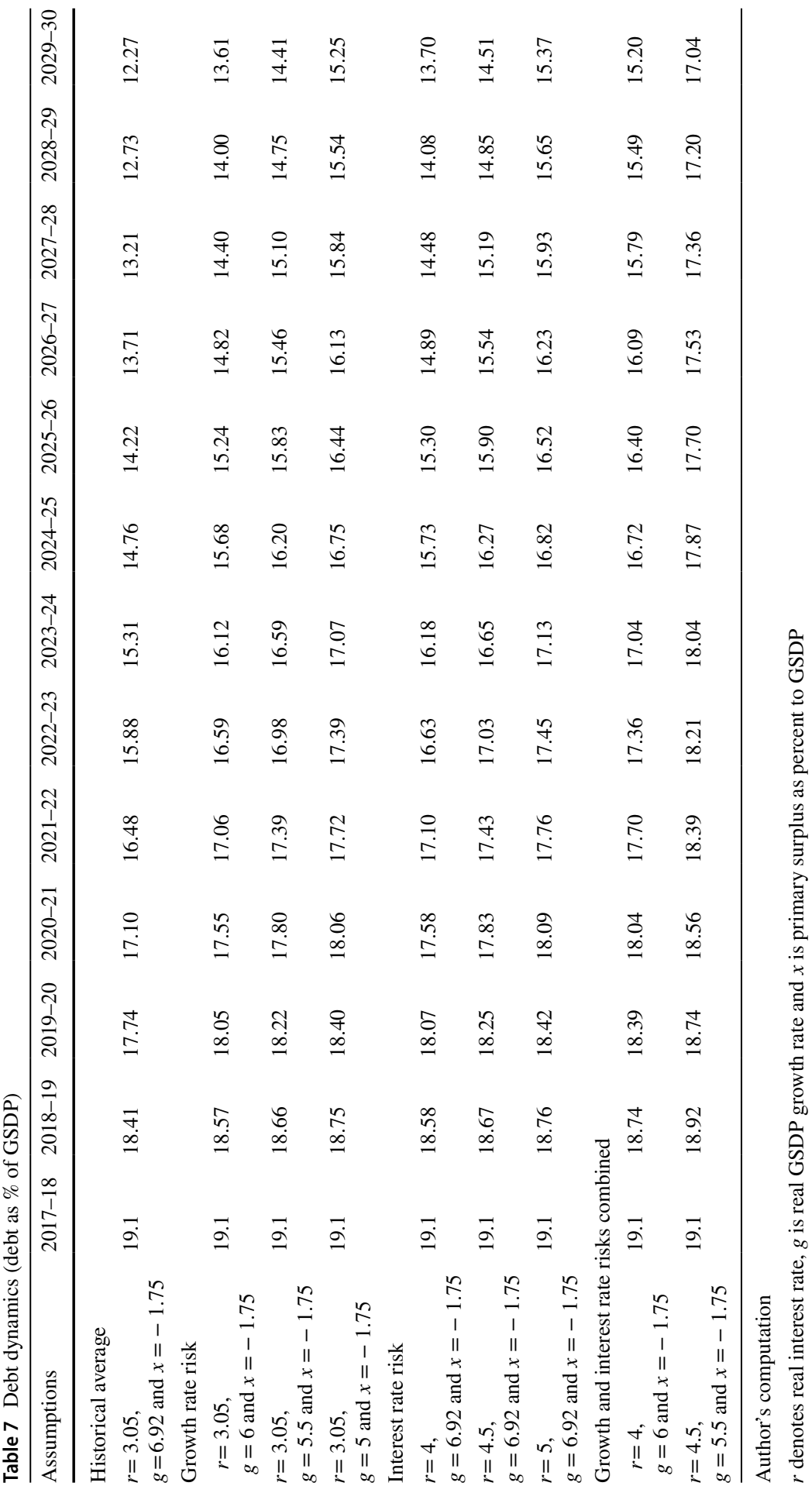




\section{Appendix 3}

See Table 8.

Source: GoK (2020a, b, c).

\section{Declarations}

Table 8 Fiscal position of Karnataka (as on November 2020)

\begin{tabular}{|c|c|c|c|c|c|}
\hline \multirow[t]{2}{*}{ Particulars } & \multicolumn{2}{|c|}{ 2019-20 (As on Nov 2019) } & \multicolumn{2}{|c|}{ 2020-21 (As on Nov 2020) } & \multirow{2}{*}{$\begin{array}{l}\text { Growth over } \\
\text { previous year } \\
(\%)\end{array}$} \\
\hline & In Rs. Crore & $\%$ to $\mathrm{BE}$ & In Rs. Crore & $\%$ to $\mathrm{BE}$ & \\
\hline Revenue receipts & 113,011 & 62.14 & 90,926 & 50.54 & -19.54 \\
\hline Own tax revenue & 66,221 & 65.09 & 56,490 & 50.44 & -14.69 \\
\hline Own non tax revenue & 4210 & 52.27 & 3945 & 50.79 & -6.3 \\
\hline Devolution from GOI & 19,914 & 50.03 & 12,192 & 42.64 & -38.77 \\
\hline GIA and contribution & 22,667 & 70.27 & 18,299 & 57.96 & -19.27 \\
\hline Total receipts & 113,075 & 62.08 & 90,976 & 50.48 & -19.54 \\
\hline Revenue expenditure & 106,909 & 58.87 & 89,757 & 49.93 & -16 \\
\hline Capital expenditure & 18,856 & 44.28 & 17,602 & 37.84 & -6.65 \\
\hline Total expenditure & 125,764 & 56.1 & 107,359 & 47.44 & -14.6 \\
\hline Public debt (receipt) & 22,413 & 46.12 & 49,872 & 94.25 & 122.51 \\
\hline Fiscal deficit & 12,689 & 30.17 & 16,382 & 35.6 & 29.1 \\
\hline Primary deficit & 2287 & 9.94 & 4270 & 17.8 & 86.7 \\
\hline
\end{tabular}

Conflict of interest It is declared that the author has no conflict of interest.

\section{References}

Adams, C., Ferrarini, B., \& Park, D. (2010). Fiscal Sustainability in Developing Asia. ADB Economics Working Paper Series 205, 1-39.

Afonso, A., \& Rault, C. (2007). What do we really know about fiscal sustainability in EU? A Panel Data Diagnostic. ECB Working Paper 820, 1-56.

Bal, D. P., \& Rath, B. N. (2014). Public debt and economic growth in India: A reassessment. Economic Analysis and Policy, 44(3), 292-300.

Barro, R. J. (1979). On the determination of public debt. Journal of Political Economy, 87(5), 940-971.

Buiter, W. H., \& Patel, U. R. (1992). Debt, deficits and inflation: An application to the public finances of India. Journal of Public Economics, 47(2), 171-205.

Burnside, C. (2005). Theoretical prerequisites for fiscal sustanability analysis. In C. Burnside, Fiscal Sustainability in Theory and Practice- A Handbook (pp. 11-34). Washington D C: The World Bank.

CAG. (2020). State finance audit report of the comptroller and auditor general of india for the year ended march 2019. Bengaluru: AG Karnataka. Retrieved from http://www.agkar.cag.gov.in/state_ finance_2019_report.asp

Dickey, D. A., \& Fuller, W. A. (1979). Distribution of the estimators for autoregressive time series with a unit root. Journal of the American Statistical Association, 74, 427-431.

Domer, E. D. (1944). The burden of public debt and the national income. American Economic Review, 34(4), 798-827. 
Gayithri, K. (2014). Evaluation of State Finances of Karnataka-submitted to Fourteenth Finance Commission, Government of India. Bengaluru: Institute for Social and Economic Change.

Gayithri, K., Chandrakanth, M. G., \& Ramanjini. (2019). Evaluation of Karnataka State Finances . Bengaluru: Institute for Social and Economic Change.

GoI. (2011). Report of the Committee on Comprehensive Review of National Small Savings Fund. New Delhi: Ministry of Finance, Government of India.

GoK. (2001). Medium term fiscal plan for Karnataka 2000-01 to 2004-05. Bengaluru: Finance Department, Government of Karnataka.

GoK. (2012). Medium term fiscal plan 2012-2016. Bengaluru: Finance Department, Government of Karnataka.

GoK. (2014). Medium term fiscal plan 2014-2018. Bengaluru: Finance Department, Government of Karnataka.

GoK. (2019). Medium term fiscal plan 2019-2023. Bengaluru: Finance Department, Government of Karnataka.

GoK. (2020). Receipts \& Expenditure at Glance upto November 2020. Bengaluru: Finance Department, Government of Karnataka. Retrieved 01 14, 2021, from https://finance.karnataka.gov.in/storage/pdffiles/AGNOV-20\%20Glance.pdf

GoK. (2020a). Budget speech 2020-21. Bengaluru: Finance Department, Government of Karnataka.

GoK. (2020b). Medium term fiscal plan 2020-2024. Bengaluru: Finance Department, Government of Karnataka.

Goyal, R., Khundrakpam, J. K., \& Ray, P. (2004). Is India's public finance unsustainable? Or, are the claims exaggerated? Journal of Policy Modelling, 26(3), 401-420.

Ianchovichina, E., Liu, L., \& Nagarajan, M. (2007). Subnational fiscal sustainability analysis: What can we learn from Tamil Nadu? Economic and Political Weekly, 42(52), 113-119.

Jha, R., \& Sharma, A. (2001). Structural breaks and unit roots: A further test of the sustainability of the Indian fiscal deficit. ASARC Working Paper, 1-26.

Kaur, B., Mukherjee, A., \& Ekka, A. P. (2017). Debt sustainability at the state level in India. MPRA Working Paper-81929, 1-37.

Maurya, N. K. (2013). Debt sustainability of a sub-national government: An assessment of the state finances of Uttar Pradesh. GIDS Working Paper-213, 1-29.

Misra, B. M., \& Khundrakpam, J. K. (2009). Fiscal Consolidation by Central and State Governments: The Medium term Outlook. Mumbai: Reserve Bank of India.

Mohanty, R. K., \& Panda, S. (2019). How does public debt affect the indian macro-economy? A structural VAR approach. NIPFP Working Paper-245, 1-34.

Perron, P. (1989). The great crash, the oil price shock, and the unit root hypothesis. Econometrica, 57(6), 1361-1401.

Pradhan, K. (2014). Is India's public debt sustainable? ISEC Working Paper-311, 1-18.

Rajaraman, I., \& Mukhopadhyay, A. (2004). Univariate time series analysis of public debt. Journal of Quantitative Economics, 2, 122-134.

Rangarajan, C., \& Srivastava, D. K. (2005). Fiscal deficits and government debt: Implications for growth and stabilization. Economic \& Political Weekly, 40(27), 2919-2934.

Rao, M. G., \& Choudhury, M. (2004). Financing human development in Karnataka. National Institute of Public Finance \& Policy.

RBI. (2013). State finances-A study of budgets of 2012-13. Mumbai: Reserve Bank of India.

RBI. (2020). RBI database on Indian states. Mumbai: Reserve Bank of India.

Uctum, M., Thurston, T., \& Uctum, R. (2006). Public debt, the unit root hypothesis and structural breaks: A multi-country analysis. Economica, 73(289), 129-156.

Vogelsang, T. J., \& Perron, P. (1998). Additional test for unit root allowing for a break in the trend function at an unknown time. International Economic Review, 39, 1073-1100.

Zivot, E., \& Andrew, D. (1992). Further evidence on the great crash, the oil price shock, and the unit root hypothesis. Journal of Business and Economic Statistics, 10(3), 25-44.

Publisher's Note Springer Nature remains neutral with regard to jurisdictional claims in published maps and institutional affiliations. 